\title{
Analysis of English Loanwords Ayat-Ayat Cinta 2 Novel
}

\author{
Suswanto Ismadi Megah S \\ English Education Department \\ University of Riau Kepulauan \\ megah76@yahoo.co.id
}

\begin{abstract}
This study is aimed to analyze the novel Ayat-ayat Cinta 2 which was written by Habibirahman El-Shirazy. This study analyzed the usage of English loanwords in the novel, particularly English phrase in the novel. The data analyzed based the descriptive qualitative research based the the text of the novel. The data found of the novel Ayat-ayat Cinta 2 is 19 data, which consist of the adjective + noun is 4 data. The Noun + noun is 12, and the Noun + adjective is 3. So, the data is mostly dominated the noun + noun. This study concluded that the usage of the English loanwords of the novel have meaning that to make conversation more easy, and the other reason is too difficult to find equal meaning in Indonesian language. In addition, English loanwords also shows a social status as the intellectual person who always used international, particularly English in his communication.
\end{abstract}

Keywords: English, phrases, loanwords, and novel

\section{INTRODUCTION}

Language is part of the tool for in communication by human being in the whole world. Communication is not happened by the similar ethnic only but occurred to the other community has immemorial also. The definite on of language includes in it a reference to society. Language is a communal possession, although admittedly an abstract one. Knowing a language also means knowing how to use that language since speakers know not only how to form sentences but also how to use them appropriately. Economics and politics are two dominant factors in the world community interaction. In an industry, the same things happened also. Particularly, the peoples will communicate through language that understandable to each other and the language used depend on correlation between speaker and listener refer to necessary on it. It means Human beings are social beings who are always committed to a certain group of people called a community. In modern era English normally 
used more than other international used in communication either oral or written communication.

English was known in Indonesia since when the British occupied Indonesia 18111816, here English was known by Netherland Indie (Indonesia) people. In addition, English also taught as compulsory subject since junior high school in Indonesia. Therefore, English is very important in Indonesia. Nowadays, English is very popular in communication or writing. So, many English words used in writing. Besides, in modern era technology grows rapidly, particularly in communication and information. Many English words mostly used in some popular communication either spoken or written. So, borrowing English words recently is very often occurred. Loan or borrowing is the usual term for the process by which a language takes new linguistic material from another language. The borrowing vocabulary from foreign language in Indonesian language is dominantly from English which has a high influence on other languages around 2 the world. The more intensive the relationship between science and technology in Indonesian people with English user society can also be the reason why it occurs in Indonesian.

The usage word "homless" and "cufflink" the novel Ayat-ayat Cinta 2 Habiburahman El-Shirazy are very often. The use of English borrowing words has spread in almost all aspects of social life in Indonesia, especially in literature. As an intellectual person, the main character of the novel who names Fahri always uses English terms in his communication.

In the literary works, English is very usual used such as in Novel which is very influenced by international culture. In the novel Ayat-ayat Cinta 2 Habiburahman El-Shirazy who was known great novelist in Millennium Era has shown his many novels used English words to colour his story. The novel of the Habiburahman's work has influenced most widely read these days. In that novel, there were found many foreign terms such as English, Arabic, Turkish, and Javanese due to the story told about Indonesian Scholar who lived in middle east and European countries named Fahri.

Therefore, finally, this study is to identify what are the types of English loanwords used in the Indonesian novel entitled Ayat-ayat Cinta 2. In addition, this study limited of the usage of English loanwords of the phrases used in the Indonesian novel entitled Ayat-ayat Cinta 2 
English loanwords or borrowing words occurded in multilingual society. This can be seen in diglossia than monolingual society or monoglossia. Indoensia can be considireded as multilingual country, therefore, foreign loanwords or borrowing words are normally occurred, particularly English recently. Individuals may be bilingual. Societies or communities are diglossic. In other words, the term diglossia describes societal or institutionalized bilingualism, where two varieties are required to cover all the community's domains but there are diglossic communities where there is very limited individual bililngualism. The criteria which identify diglossic communities were initially interpreted very stringently, so that few communities qualified as diglossic. Soon, however, it became clear that some sociolinguists felt that the term could usefully be extended.

When elements of a foreign culture and language are 'borrowed' into the culture and language of another, they became adapted to their new cultural and linguistic context. Most English words taken into Japanese show orthographical, phonological, structural or semantic integration into the native linguistic system.

The examples of loanwords in the English include Cafe (from French café, which literally means "coffee"), bazzar (from Persian $b \bar{a} z \bar{a} r$, which means "market"), and kindergarten(from German Kindergarten, which literally means "children's garden"). Loans of multi-word phrases, such as the English use of the French term déjà vu, are known as adoptions, adaptations, or lexical borrowings. Strictly speaking, the term loanword conflicts with the ordinary meaning of loan in that something is taken from the donor language without it being something that is possible to return.

In English loanwords of the text can be as lexemes, phrase and sentences. In this study, which is very intersing is phrase in the novel. According to Giyoto (2006) a phrase is a group of words that a head. The phrases can be Noun phrase, verb Phrase, adjective phrase, infinitive phrase, Gerund phrase, and participle phrase.

\section{METHODOLOGY}

\section{Data Source}

In this study, the data source used is a prominent Indonesian novel entitled Ayatayat Cinta 2 Manusia written by a greatly-famous Indonesian novelist, Habiburahman El- 
Shirazy (2015). This novel contains many foreign terms such as English, Arabic, Turkish, and Javanese but this study focused on the English loanwords in Indonesian novel.

\section{Technique of Collecting Data}

This study considered as library research method which was done by making observation in the library such as reading and noting down the sources related with the topic. Therefore, this method and the techniques to be acted out can be specifically described by some paths. First of all, the data source, in this study of the novel of Ayat-ayat Cinta 2 written by a greatly-famous Indonesian novelist, Habiburahman El-shirazy (2015). The subsequent steps were reading and observing the novel and then checking all the words and terms that belong to the English loanwoords. Afterwards, it was followed by taking note of the important matters of the data. This study is limited of the English loanwords found in the novel of Ayat-ayat Cinta 2 and classifying them based on their types of phrases used in this novel.

\section{Technique of Analyzing}

In this study the Data collected were descriptively analyzed by using qualitative method based on Haugen's theory of types of borrowing words. In qualitative research, the use of theory is much more varied. So, these steps can illuminate the process of analyzing the data. Firstly, English borrowing words or loanwords found the novel of Ayat-ayat Cinta 2 were identified. In analyzing the data, it was analyzed based on the types of loanwords and phrases of the loanwords. The last is this study limited of the phrases of lexical English loanwords in this study. And then the novel entitled Ayat-ayat Cinta 2 shortened alphabetically (AAC 2).

\section{RESULTS}

In this study, the Indonesian novel entitled Ayat-ayat Cinta 2. The Types of English borrowing words or loanwords In this data analysis will be discuused types of phrase and the meaning of the English usage in the novel. This can be seen in following data below: 
English phrases can formed from some parts of speech. Therefore, to make more easily to analyze noun phrase can be such kinds of formations. Those formations are Adjective + noun, Adjective + noun, gerund + noun, participle + noun, and noun + noun .

\section{The adjective + noun}

This formation, the head is noun while the adjective is as modifier. This can be seen in following data.

\section{Data 1}

Suara bagpies menggema dari plaza int Giles Cathedral yang berdiri anggun menawan (AAC2, 2015:1)

It is based on the data 1 above that the usage of English word bagpies is to show that kinds of flute but this originally from Scottish tradition. Therefore, the usage of bagpies is to give emphizes kind of tradition of the Scottish flute.

\section{Data 2}

Saya rasa karena ada semacam shortcrust kue-nya.(AAC2, 2015:91)

It is based on the data 2 above that the usage of English word shortcrust is to show that shortcrust is the kind of ingredient in the cake it is used to make the cake more deliscious.

\section{Data 3}

Misbah memotonya dengan smartphone-nya.(AAC2, 2015:173)

It is based on the data 3 above that the usage of English word smartphone is to show that smartphone is the kind of phone with complete features, therefore, this phone may also work as the camera. 


\section{Data 4}

“Iya. Tapi lewat resto dan Agnina minimarket.(AAC2, 2015:323)

It is based on the data 4 above that the usage of English word minimarket is to show that minimarket is the kind of the shop which sells various kinds of goods. Because of the complete goods it sells, therefore, this is considered as small market.

\section{The Noun + noun}

This formation, the head is noun as the head and the other is as modifier. This can be seen in following data.

\section{Data 5}

Panoramanya seumpama postcard hidup (AAC2, 2015:2)

It is based on the data 5 above that the usage of English word postcard is to show that kind of paper, this compare the scenery and the card.

\section{Data 6}

Namun Fahri masih bekerja merampungkan editing hasil riset untuk postdoc-nya(AAC2, 2015:23)

It is based on the data 6 above that the usage of English word postdoc is to show that postdoc is the degree after finishing doctoral program. This step done more research in this study, this done by Doctors.

\section{Data 7}

Saya Taher Khan, pengajar physiotheraphy di Queen Margaret University(AAC2, 2015:46) 
It is based on the data 7 above that the usage of English word physiotheraphy is to show that physiotheraphy is the kind of job which concerns of psychological diseases and how to treat the diseases.

\section{Data 8}

Paman Hulusi membawa mobil SUV itu menuju hotel yang telah menjadi landmark Kota Edinburgh.(AAC2, 2015:60)

It is based on the data 8 above that the usage of English word Iandmark is to show that landmark is the kind of place which consist of the land, flower and artistic building. This is symbol of the city.

\section{Data 9}

Brenda mengambil pena and blocknote kecil dari tasnya dan menyerahkan kepada Fahri.(AAC2, 2015:98)

It is based on the data 9 above that the usage of English word blocknote is to show that blocknote is the small book used take notes or something important or special, because of small size, so it is easy to bring anywhere.

\section{Data 10}

Tanpa payung, memakai jaket yang berpenutup kepala, tampaknya waterproof.(AAC2, 2015:125)

It is based on the data 10 above that the usage of English word waterproof is to show that waterproof is the kind of the raincoat, this may protect the body from the rain falls.

\section{Data 11}

Fahri bangkit dan mengambil earphone di laci mejanya.(AAC2, 2015:267) 
It is based on the data 11 above that the usage of English word earphone is to show that earphone is the kind of phone utensil used in the ear to make the sound louder and clearer.

\section{Data 12}

Nasi goring seafood dengan telur ceplok mata sapi.(AAC2, 2015:395)

It is based on the data 12 above that the usage of English word seafood is to show that seafood is the kind of the food which is source from the sea such fish, shrimp, creep, etc. therefore, this food called seafood.

\section{Data 13}

Sore itu ia memakai suit atau jas, lengkap dengan waiscost atau rompi, kemeja double cuff, kemudian cufflink dan dasi.(AAC2, 2015:560)

It is based on the data 13 above that the usage of English word waiscost is to show that waiscost is the kind of the clothes used after the dress, this used in formal meeting.

\section{Data 14}

Untuk celana , ia memakai celana bhan woolblend.(AAC2, 2015:560)

It is based on the data 14 above that the usage of English word woolblend is to show that woolblend is the kind of the raw material for making trousers. This is expensive material used for expensive dress.

\section{Data 15}

Penampilan Fahri tampak mewah dengan kemeja double cuff dengan cufflink.(AAC2, 2015:560) 
It is based on the data 15 above that the usage of English word cufflink is to show that cufflink is the kind of jewelry to make social status of the user considered as the high level social status.

\section{Data 16}

Penampilan Fahri tampak mewah dengan kemeja double cuff dengan cufflink.(AAC2, 2015:560)

It is based on the data 16 above that the usage of English word cufflink is to show that cufflink is the kind of jewelry to make social status of the user considered as the high level social status.

\section{The Noun + Adjective}

This formation, the head is adjective as the head and the noun is as modifier. This can be seen in following data.

\section{Data 17}

Yang wireless, jadi mudah pasangnya, dan kamreanya mudah disembunyika.(AAC2, 2015:132)

It is based on the data 17 above that the usage of English word wireless is to show that wireless is the kind of camera without any wire. So, it is easy to install it.

\section{Data 18}

Kita akan sangat malu kalau saudara kita yang homeless it uterus diberitakan.(AAC2, 2015:175)

It is based on the data 18 above that the usage of English word homeless is to show that homeless is the kind ofs to someone who does not have house or home to protect them. 


\section{Data 19}

"Perempuan itu sama sekali tidak menyadari bacaanya di samping pintu kamar hospital itu.(AAC2, 2015:373)

It is based on the data 19 above that the usage of English word hospital is to show that hospital is the kind of the house which is very vital for sick person. In Indonesian language called “rumah sakit” (literally translated, sick house).

The data found of the novel Ayat-ayat Cinta 2 is 19 data, which consist of the adjective + noun is 4 data. The Noun + noun is 12 , and the Noun + adjective is 3 . So, the data is mostly dominated the noun + noun.

\section{DISCUSSION}

In this study can be conclude that the main character of the Novel Ayat-ayat Cinta 2, named Fahri is an intellectual Indonesian scholar. He always used some English terms in his conversation. This study analyzed how the English loanwords, particularly English phrase found in the Indonesian novel of the Habibirahman El-Shirazy's novel.

The data found of the novel Ayat-ayat Cinta 2 is 19 data, which consist of the adjective + noun is 4 data. The Noun + noun is 12 , and the Noun + adjective is 3 . So, the data is mostly dominated the noun + noun.

The English loanwords of the novel have meaning that to make conversation more easy, and the other reason is too difficult to find equal meaning in Indonesian language. In addition, English loanwords also shows a social status as the intellectual person who always used international, particularly English in his communication.

\section{REFERENCES}

El-Shirazy, Habiburrahman. (2015). Ayat-ayat cinta2. Republika.

Giyoto. (2006). Grammar II , Surakarta: IAIN Surakarta Press 